\title{
PERSEPSI HARGA, KUALITAS PRODUK DAN KETERSEDIAAN KERUPUK AMPLANG TERHADAP LOYALITAS KONSUMEN DI KABUPATEN SAMBAS
}

\author{
Dian Sari' ${ }^{1}$, Andi Maryam ${ }^{2}$ \\ ${ }^{1}$ Politeknik Negeri Sambas, Jalan Raya Sejangkung Desa Sebayan Kabupaten Sambas \\ ${ }^{2}$ Politeknik Negeri Sambas, Jalan Raya Sejangkung Desa Sebayan Kabupaten Sambas \\ Email $^{1}:$ diansari17@gmail.com \\ Email $^{2}$ :_andimaryam1985@gmail.com
}

\begin{abstract}
ABSTRAK
Ketika konsumen membeli kerupuk amplang, hal awal yang sering diperhatikan calon konsumen adalah harga, kemudian produk yang akan dibeli, kualitas serta ketersediaannya. Kepuasan pasca pembelian akan mendorong konsumen membeli dan mengkonsumsi ulang produk tersebut atau loyal. Sehingga penelitian ini bertujuan untuk mengetahui persepsi harga, kualitas dan ketersediaan produk kerupuk amplang terhadap loyalitas konsumen di Kabupaten Sambas. Lokasi penelitian dilakukan secara sengaja (purposive) dengan beberapa pertimbangan, dimana amplang di kabupaten Sambas termasuk produk yang baru dipasarkan sehingga perlu dilakukan studi mengenai persepsi harga, kualitas produk dan ketersediaan kerupuk amplang terhadap kepuasan konsumen. Jenis penelitian yang dilakukan adalah penelitian deskriptif. Metode pengambilan sampel dilakukan dengan menggunakan metode accidental sampling Dengan jumlah sampel sebanyak 100 orang. Teknik Analisis data menggunakan menggunakan Uji Validitas, Uji Reliabilitas dan analisis Regrasi berganda. Dari hasil penelitian ini diketahui Secara keseluruhan atribut meliputi harga, kualitas dan ketersediaan kerupuk amplang mempunyai pengaruh yang signifikan terhadap loyalitas konsumen.
\end{abstract}

Kata kunci: harga, ketersediaan produk, kualitas, Loyalitas

\section{PENDAHULUAN}

Umumnya masyarakat modern dewasa ini ditandai dengan aktivitas kerja yang tinggi, khususnya yang terletak di perumahan, perkantoran dan sekolah. Mobilitas kegiatan tersebut berdampak pada semakin banyak orang menghabiskan waktunya di luar rumah karena banyaknya kegiatan, khususnya kalangan pelajar, mahasiswa dan karyawan yang sebagian besar dari mereka lebih suka mencari jenis makanan ringan dengan harga yang murah dan memiliki citra rasa yang enak dan berkualitas. Sehingga pada jaman sekarang ini banyak sekali jenis ukm makanan.

Kabupaten sambas merupakan salah satu daerah yang mempunyai banyak sekali jenis usaha makanan ringan, salah satunya dari hasil olahan ikan. Salah satu hasil unit usaha kecil menengah keatas (UMKM) olahan ikan adalah kerupuk amplang. Usaha krupuk amplang ini merupakan industri rumah tangga yang mulai digeluti oleh masyarakat Kabupaten Sambas sejak sekitar tahun 2014. Terutama di kecamatan selakau dan pemangkat. Usaha amplang di Kecamatan Selakau dan kecamatan pemangkat untuk pengembangannya sampai saat ini sudah cukup baik. Dengan adanya dukungan ketersediaan bahan baku ikan tenggiri baik dari tangkapan perairan, tangkapan alam dan modal yang diberikan oleh pemerintah baik berupa peralatan usaha maupun pelatihan-pelatihan bagi pengusaha untuk dapat terus berkembang. Kesempatan untuk memasarkan produk juga begitu luas. Pemasaran produk awalnya hanya dengan menitipkan di toko atau di warung. Pemasaran hampir di seluruh kabupaten yaitu kota yang ada di Kalimantan Barat, yaitu Sambas, Singkawang, Bengkayang, dan Pontianak bahkan ke Jakarta.

Ketika konsumen membeli kerupuk amplang, hal awal yang sering diperhatikan calon konsumen adalah harga, kemudian produk yang akan dibeli, baik tampilan maupun ketersediaannya. Harga dan kualitas 
produk adalah hal penting bagi konsumen. Kotler dan Amstrong (2011) menyatakan harga menjadi faktor utama yang mempengaruhi pilihan seorang pembeli. Penetapan harga pada suatu produk makanan haruslah sesuai dan wajar dengan kualitas produk yang ditawarkan. Tingginya harga yang ditawarkan tersebut harus sesuai dengan manfaat yang akan diterima oleh konsumen yang mengkonsumsinya. Harga yang terlalu tinggi dan terlalu rendah akan mempengaruhi minat beli konsumen. Harga yang terlalu tinggi akan membuat konsumen beralih ke produk lain yang sejenis tetapi dengan harga yang lebih murah, begitu sebaliknya, jika harga yang ditawarkan terlalu rendah konsumen akan ragu dengan kualitas produk yang ditawarkan tersebut sehingga mengurangi minat beli akan produk tersebut. Selanjutnya, tingginya kualitas produk yang ditawarkan akan menarik minat beli konsumen, begitu juga sebaliknya. Jika pemasar memperhatikan kualitas, bahkan diperkuat dengan periklanan dan harga yang wajar maka konsumen tidak akan berpikir panjang untuk melakukan pembelian terhadap produk (Kotler dan Amstrong, 2009). Ketersediaan barang merupakan wujud kesiapan produsen dalam menyediakan produknya dan juga melihat sejauh mana sikap konsumen terhadap ketersediaan produk yang ada. Semakin produk tersebut sesuai dengan ketepatan waktu dalam ketersediaannya maka akan mempengaruhi intensitas pembelian konsumen. Hal ini sesuai dengan pernyataan Kotler (2005) bahwa salah satu faktor yang mempengaruhi minat beli konsumen adalah faktor ketersediaan produk.

Pentingnya sebuah kepuasan seseorang terhadap suatu produk atau jasa tentunya dapat menentukan citra produk atau jasa tersebut di masyarakat. Kepuasan pelanggan menurut Zeithaml, Bitner dan Dwayne (2009) adalah penilaian pelanggan atas produk ataupun jasa dalam hal menilai apakah produk atau jasa tersebut telah memenuhi kebutuhan dan ekspektasi pelanggan.Semakin kuat kepercayaan konsumen terhadap produk semakin kuat pula loyalitas yang dimiliki oleh konsumen. Menurut peneliti terdahulu Steven Darwin dan Yohanes Sondang Kunto (2014) Loyalitas konsumen akan terbangun ketika terdapat kepercayaan konsumen terhadap perusahaan dan kualitas produk yang memuaskan dari produsen terhadap konsumen. Kepercayaan sebagai pernyataan yang melibatkan harapan positif yang meyakinkan berkenaan dengan seseorang dalam sesuatu yang berisiko, dalam hal ini kepercayaan merupakan keyakinan yang dimiliki konsumen terhadap suatu produsen bahwa produsen akan bersikap baik terhadap konsumennya. Dari uraian diatas maka tujuan dalam penelitian ini adalah untuk mengetahui persepsi konsumen amplang terhadap harga, kualitas dan ketersediaan produk terhadap loyalitas konsumen serta mengetahui apakah harga, kualitas dan ketersediaan produk yang mempunyai pengaruh paling dominan terhadap loyalitas konsumen.

Penelitian ini bermanfaat dalam melakukan proses strategi pemasaran karena konsumen menjadi dasar yang amat penting dalam pemasaran atau ujung tombak dari pemasaran. konsumen memiliki persepsi tehadap suatu produk apakah produk tersebut baik atau buruk secara kualitas, harga, bentuk, dan manfaat sebelum ia mengambil keputusan pembelian dan berdampak kepada kepuasan konsumen. Kepuasan konsumen merupakan faktor penentu keberhasilan pelaksanaan fungsi pemasaran. Konsumen yang puas di harapkan terus loyal kepada perusahaan. Sehingga setiap pemasar berkewajiban untuk memahami konsumen untuk meraih kesuksesan dalam menjalankan bisnisnya.

\section{METODE}

\section{Lokasi dan waktu penelitian}

Lokasi penelitian ditentukan secara sengaja (purposive) yaitu di Kabupaten Sambas. Pemilihan lokasi penelitian dilakukan secara sengaja (purposive) dengan beberapa pertimbangan, dimana amplang di kabupaten Sambas termasuk produk yang baru dipasarkan sehingga perlu dilakukan studi mengenai persepsi harga, kualitas produk dan ketersediaan kerupuk amplang terhadap kepuasan konsumen. Waktu penelitian dimulai dari bulan maret 2019 sampai dengan bulan November 2019 


\section{Metode Pengambilan Sampel}

Metode pengambilan sampel dilakukan dengan menggunakan metode accidental sampling. Accidental Sampling adalah teknik penentuan sampel berdasarkan kebetulan, yaitu konsumen yang secara kebetulan/insidental bertemu dengan peneliti dapat digunakan sebagai sampel, bila dipandang orang yang kebetulan ditemui itu cocok sebagai sumber data. Keputusan pengambilan sampel harus mempertimbangkan desain sampel dan ukuran sampel. Roscoe dalam Sekaran (2006) menyatakan bahwa ukuran sampel lebih dari 30 dan kurang dari 500 adalah tepat untuk kebanyakan penelitian. Responden dalam penelitian ini diambil sebanyak 100 responden dikarenakan jumlah tersebut telah melebihi batas terkecil dari pendapat Roscoe.

\section{Teknik Pengumpulan dan Sumber Data}

\section{a. Teknik Pengumpulan Data}

1. Kuesioner, yaitu teknik pengumpulan data dengan menggunakan daftar pertanyaan yang sifatnya tertutup, yaitu jawabannya telah tersedia sehingga tinggal memilih Kuesioner digunakan untuk mengambil data pokok secara langsung dari responden. Pengukuran kuesioner digunakan skala Likert.

2) Studi pustaka, yaitu pengumpulandata yang diperoleh melalui data-data dokumen dan literatur, yaitu teori, penelitian terdahulu, dan datadokumentasi tentang data gam-baran umum perusahaan

3) Interview, yaitu proses pengumpulan data yang dilakukan dengan secara langsung melalui wawancara.

\section{b. Sumber Data}

1) Data primer, yaitu data yang diper-oleh secara langsung dari respon-den, khususnya data yang diperolehberdasarkan pada jawaban respon-den terhadap kuesioner.

2) Data Sekunder, yaitu bersumberdari informasi yang berasal dari berbagai literatur seperti buku, jurnal yang berhubungan dengan objek penelitian.

\section{Teknik Analisis Data}

Teknik analisis data dalam penelitian ini mengunakan teknik analisis regresi berganda. Analisis regresi linier berganda adalah regresi linier untuk menganalisis besarnya hubungan dan pengaruh variabel independen yang jumlahnya lebih dari dua (Suharyadi dan Purwanto, 2004). Sebelum analisis regresi berganda dilakukan, terlebih dahulu dilakukan uji persyaratan analisis, yaitu: uji validitas dan uji reabiliitas. Uji validitas digunakan untuk mengukur valid dan tidak validnya suatu kuesioner. Kuesioner dikatakan valid jika kuesioner mampu mengungkapkan sesuatu yang akan diukur oleh kuesioner tersebut. Uji reabilitas adalah alat untuk mengukur suatu kuesioner yang merupakan indikator dari variabel . Butir kuesioner dikatakan reliabel atau andal apabila jawaban seseorang terhadap kuesioner adalah konsisten.

Adapun persamaan model regresi berganda tersebut adalah (Suharyadi dan Purwanto, 2011).

$$
\mathrm{Y}=\mathrm{a}+\mathrm{b} 1 \mathrm{X} 1+\mathrm{b} 2 \mathrm{X} 2+\ldots+\mathrm{bkXk}
$$

Keterangan:

$\begin{array}{ll}\mathrm{Y} & : \text { nilai prediksi dari } \mathrm{Y} \\ \mathrm{a} & : \text { bilangan konstan } \\ \mathrm{b} 1, \mathrm{~b} 2, \ldots, \mathrm{bk} & : \text { koefisien variabel bebas } \\ \mathrm{x} 1, \mathrm{x} 2, & : \text { variabel independen } \\ \mathrm{x} 1 & : \text { harga } \\ \mathrm{x} 2 & : \text { kualitas produk } \\ \mathrm{x} 3 & : \text { ketersediaan produk }\end{array}$

\section{HASIL DAN PEMBAHASAN}

Uji realiabilitas dapat dilihat dari semua butir pertanyaan yang digunakan untuk mencari data mengenai semua variabel kerupuk amplang mempunyai $r$ hitung lebih besar dari $r$ tabel ( $r$ hitung $\geq r$ tabel). Maka semua butir pertanyaan untuk variabel harga konsumen kerupuk amplang dinyatakan Valid. Uji reliabilitas dilihat dari nilai a Cronbach, dengan kriteria bila a Cronbach > 0,60 maka variabel tersebut dinyatakan reliabel. Dari hasil pengolahan data diperoleh bahwa nilai Alpha Cronbach lebih besar dari 0,6 untuk semua item pengukuran. Sehingga bisa dikata kan 
bahwa item variabel harga (X1), kualitas (X2), dan ketersediaan (X3) untuk mengukur Loyalitas (Y) terbukti reliabel atau konsisten dalam pengukuran.

Berdasarkan hasil analisis diperoleh persamaan regresi berganda sebagai berikut

$\mathrm{Y}=\mathrm{a}+\mathrm{b} 1 \mathrm{X} 1+\mathrm{b} 2 \mathrm{X} 2+\mathrm{b} 2 \mathrm{X} 3$

$Y=6,965+0,161 X 1+0,15 X 2+0,169 X 3$

Dari persamaan tersebut diketahui konstanta besarnya 6,965 yang dengan koefisien harga (X1), kualitas (X2) dan ketersediaan (X3) bernilai nol (0) maka diperoleh nilai loyalitas nasabah sebesar 6,965 satuan. Ini berarti walaupun tanpa harga, kualitas dan ketersediaan nilai loyalitas konsumen tetap ada dan positif.

Nilai koefisien harga sebesar 0,161 hal ini menunjukkan setiap perubahan variabel prediktor harga (X1) sebesar satu satuan akan mengakibatkan perubahan yang positif pada loyalitas konsumen sebesar 0,161 . Artinya semakin sesuai harga dengan kualitas produk dan semakin rendah harga di banding pesaing maka akan meningkatkan loyalitas sebesar 0,161 satuan. Dengan anggapan variabel lainnya tetap. Jika dibandingkan dengan variabel lain, besaran koefisien pengaruh harga berada pada urutan kedua terbesar terhadap keputusan pembeliaan ulang atau loyalitas. Hal ini dikarenakan adanya kesesuaian harga terhadap kualitas produk, kesesuaian harga dengan harga pasar, kesesuaian harga dengan manfaat, harga yang kompetitif dari pesaing mampu memenuhi keinginan konsumen. Terpenuhinya keinginan konsumen menimbulkan rasa kepuasan yang berdampak pada keinginan untuk membeli lagi, merekomendasikan, tidak berpaling serta memberikan rekomendasi kepada orang lain.

Nilai koefisien kualitas 0,157 hal ini menunjukkan setiap perubahan variabel prediktor kualitas (X2) sebesar satu satuan akan mengakibatkan perubahan yang positif pada loyalitas konsumen sebesar 0,157. Namun sebaliknya jika terjadi penurunan satu satuan prediktor kualitas berakibat berkurangnya loyalitas sebesar 0,157 satuan dengan anggapan variabel bebas lainnya tetap. Jika dibandingkan dengan variabel lain, besaran koefisien pengaruh kualitas pada urutan ketiga terhadap keputusan pembelian ulang atau loyalitas. Hal ini dikarenakan adanya kecocokan dalam citarasa produk, kemampuan memberikan hasil seperti yang di inginkan dan kandungan yang aman pada produk. Kualitas produk yang tinggi dapat memenuhi keinginan untuk mengulangi pembelian kembali yang lebih besar dari pelanggan serta menyebabkan loyalitas. Sesuai dengan penelitian terdahulu menurut Suwarni (2011), terdapat pengaruh yang signifikan antara kualitas produk terhadap loyalitas konsumen;

Nilai koefisien ketersediaan 0,169 hal ini menunjukkan setiap perubahan variabel prediktor ketersediaan (X3) sebesar satu satuan akan mengakibatkan perubahan yang positif pada loyalitas konsumen sebesar 0,169. Namun sebaliknya jika terjadi penurunan satu satuan prediktor harga berakibat berkurangnya loyalitas 0,169 satuan dengan anggapan variabel bebas lainnya tetap. Jika dibandingkan dengan variabel lain, besaran koefisien pengaruh ketersediaan pada urutan pertama terhadap keputusan pembelian ulang atau loyalitas. Ini berarti bahwa meningkatnya ketersediaan produk mampu meningkatkan loyalitas pelanggan sebesar 0,169 satuan. Kemampuan ketersediaan produk dalam meningkatkan loyalitas pelanggan disebabkan semakin tersedianya produk yang dijual membuat pelanggan tidak banyak mengeluarkan tenaga untuk membeli produk yang diinginkan. Hal ini di karenakan adanya kemudahan produk untuk ditemukan di pasaran, Ketersediaan produk di pasaran dan fasilitas dan kenyamanan lokasi penjualan produk. Ketersediaan produk yang diberikan sesuai dengan kebutuhan sehingga dapat memenuhi keinginan dari konsumen dan akan menimbulkan kepuasan yang berdampak pada loyalitas dari konsumen. 


\section{KESIMPULAN}

Berdasarkan hasil penelitian mengenai pengaruh persepsi harga, kualitas, dan ketersediaan kerupuk amplang terhadap loyalitas konsumen dapat disimpulkan Secara keseluruhan harga, kualitas dan ketersediaan kerupuk amplang mempunyai pengaruh yang signifikan terhadap loyalitas konsumen. Semua atribut akan mampu memenuhi harapan dan keinginan konsumen sehingga pelanggan merasa terpuaskan yang berdampak pada tingginya loyalitas pelanggan terhadap produsen yang memenuhi harapan dan keinginan tersebut. Karena ternyata dari hasil penelitian harga, kualitas dan ketersediaan menjadi faktorfaktor yang mempengaruhi tingkat loyalitas pelanggan, maka produsen kerupuk amplang harus lebih memperhatikan lagi faktor tersebut. Harga kerupuk amplang untuk tetap disesuaikan dengan kualitas yang ditawarkan. Bagi peneliti selanjutnya diharapkan mampu menambahkan variabel lain yang dapat mempengaruhi loyalitas konsumen. Karena di penelitian ini hanya menggunakan variabel harga, kualitas dan ketersediaan produk sehingga masih dianggap kurang dalam loyalitas konsumen.

\section{DAFTAR PUSTAKA}

Darwin,Steven dan Kunto, Yohanes.2014. Analisis Pengaruh Kualitas Layanan Terhadap Loyalitas Pelanggan Dengan Kepuasan Dan Kepercayaan Pelanggan Sebagai Variabel Intervening Pada Asuransi Jiwa Manulife Indonesia. Surabaya. Jurnal Manajemen Pemasaran Petra, Vol 2, No.1

Griffin, Jill. 2005. Customer Loyalty. Jakarta : Erlangga.

Kotler, Philip. 2005. "Manajemen Pemasaran", Edisi ke Sebelas Jilid 1. PT Indeks kelompok Gramedia. Jakarta.

Kotler, Philip dan Kevin Lane Keller.2009. Manajemen Pemasaran, edisi 13, Jakarta.Erlangga.

Kotler, Philip. dan Keyin,Lane Keller. 2011, Manajemen PemasaranJilid I Edisi ke 13. Jakarta: Erlangga.

Rahman,Syaifur.Dkk.2004.Strategi bersaing pada industri kerupuk Amplang jurnal Agrointek. vol.8 No.2 Universitas Trunojoyo Madura. Bangkalan Madura
Rangkuti F.2002.Measuring Customer Satisfaction.Jakarta.Gramedia Pustaka Utama

Sekaran, Uma. 2006. Research Methods For Business : Metodologi Penelitian untuk Bisnis Buku 1 Edisi 4. Jakarta : Salemba Empat

Septia,Suwarni. 2011. Pengaruh Kualitas Produk dan Harga terhadap Loyalitas melalui Kepuasan Konsumen.JURNAL EKONOMI BISNIS, TH. 16, NO 1.

Sugiyono. 2008. Metode penelitian kuantitatif, kualitatif, dan R\&D. Bandung : Alfabeta

Zeithaml, V.A., Bitner, M.J. \& Gremler, D.D. 2009. Services marketing: Integrating customer focus across the firm (5th ed). New York: McGraw-Hill, Inc 